\title{
KESEJAHTERAAN ANJING DALAM PEMBERANTASAN WABAH RABIES DI HINDIA BELANDA
}

\author{
Budi Gustaman \\ Departemen Sejarah \& Filologi \\ Fakultas Ilmu Budaya, Universitas Padjadjaran \\ budi.gustaman@unpad.ac.id
}

\begin{abstract}
Abstrak
Rabies telah menjadi masalah serius di Hindia Belanda sejak abad ke-19. Faktor utamanya adalah banyaknya jumlah anjing yang tidak dirawat (andjing kampong) di Jawa dan Sumatra. Hal ini membuat Pemerintah Kolonial membuat regulasi untuk menangkap dan membunuh anjing yang terinfeksi. Permasalahannya ialah pemberantasan rabies diwarnai praktik-praktik kekerasan terhadap anjing. Nederlandsch-Indische Vereeniging Bescherming can Dieren, sebuah perkumpulan pecinta hewan memprotes bahwa pembunuhan tersebut adalah suatu "kejahatan" karena tidak mengindahkan aspek-aspek kesejahteraan satwa. Selanjutnya, perkumpulan ini pun merekomendasikan cara-cara yang "lunak" dalam membunuh anjing. Disadari atau tidak, persoalan kekerasan ini pada dasarnya masih terjadi hingga sekarang seiring masih mewabahnya rabies di beberapa tempat di Indonesia. Tulisan ini setidaknya memberikan refleksi historis dalam penanggulangan rabies yang lebih memperhatikan kesejahteraan satwa.
\end{abstract}

Kata kunci: rabies, anjing, kesejahteraan satwa

\begin{abstract}
Rabies had become a serious problem in Netherlands Indie since the 19th century. The main factor was a large number of untreated rabid dogs (andjing kampong) in Java and Sumatra. This condition forced the Colonial Government to issue the regulation to catch and eliminate rabid dogs. However, the eradication of rabies posed another problem, that is violence against dogs. Nederlandsch-Indische Vereeniging Bescherming can Dieren, an association of animal lovers protested that murder was a crime. Furthermore, this association recommended soft ways to kill dogs. Knowingly or not, the issue of violence largely still occurs today as there have been outbreaks of rabies in several places in Indonesia. This paper at least provides a historical reflection in the handling of rabies that is more concerned with animal welfare.
\end{abstract}

Keywords: rabies, dog, animal welfare

\section{PENDAHULUAN}

"Pemkab Sumbawa Nusa Tenggara Barat (NTB) menyatakan akan memberlakukan status kejadian luar biasa (KLB) rabies hingga dua tahun ke depan. Sejauh ini, sudah hampir seribu anjing dimatikan."1

Pada 19 Maret 2019, laman detik.com melansir berita terkait wabah rabies yang

${ }^{1}$ Kalimat ini merupakan penggalan berita yang dikutip dari detik.com, 19 Maret 2019, “ KLB Rabies, Sudah 987 Anjing Dimatikan di Sumbawa NTB", https://news.detik.com/berita/d4473941/klb-rabies-sudah-987-anjing-dimatikan-di-sumbawa-ntb, diakses 16 Desember 2019. 
melanda Nusa Tenggara Barat. “Pemkab Sumbawa Nusa Tenggara Barat (NTB) menyatakan akan memberlakukan status kejadian luar biasa (KLB) rabies hingga dua tahun ke depan. Sejauh ini, sudah hampir seribu anjing dimatikan." Disebutkan bahwa telah ada 81 warga yang terinfeksi rabies di Kabupaten Sumbawa. Penanggulangan wabah dilakukan dengan cara eliminasi (dibunuh) dan vaksinasi. Adapun upaya eliminasi yang dilakukan ialah dengan cara diracun dan ditembak.

Dari penggalan berita tersebut, ada dua narasi penting yang bisa dikemukakan. Pertama, merebaknya wabah rabies tidak lepas dari tingginya kuantitas pemeliharaan anjing, yang tidak diimbangi dengan kualitas higienitasnya. Kedua, pembunuhan anjing yang terinfeksi rabies merupakan suatu keharusan untuk meminimalisir penularan. Poin terakhir merupakan hal yang dianggap wajar untuk memutus benang merah penularan wabah. Namun demikian, patut dipertanyakan "kualitas" cara membunuh tersebut: apakah sesuai dengan kaidah kesejahteraan satwa? Hal yang tidak pernah terulas di ranah publik, yang mengacu pada pertanyaan lanjutan: sudah sesuai kah? atau memang ada faktor ketidaktahuan (bahkan ketidakpedulian) terhadap hal tersebut?

Jika mengacu pada salah satu konsep dasar kesejahteraan satwa menurut Farm Animal Welfare Council (FAWC) - bahwa satwa harus bebas dari rasa sakit - maka prosedur pembunuhan pun harus dilakukan dengan cara yang "tidak menyakitkan" atau meminimalisir rasa sakit saat kematiannya. Pemberantasan rabies pun harus disandarkan pada prinsip tersebut. Kasus tersebut pada dasarnya pernah terjadi di Jawa seiring dengan merebaknya wabah rabies pada awal abad ke-20. Para pemerhati kesejahteraan satwa membuat cara khusus untuk membunuh anjing yang terinfeksi rabies. Hal ini didasarkan atas keresahan atas prilaku pembunuhan anjing yang cenderung "seenaknya" tanpa memperhatikan kondisi anjing yang begitu ketakutan dan menderita saat dan sebelum dibunuh.

Tulisan ini mencoba menyajikan fakta terkait upaya para pemerhati kesejahteraan satwa dalam menyikapi pemberantasan rabies di Hindia Belanda pada awal abad ke-20. Wabah ini ternyata menyisakan berbagai polemik. Selain tentu mengarah pada upaya pengobatan \& pemberantasan penyakit, persoalan rabies mengarah pula pada isu-isu seputar kesejahteraan satwa. Anjing-anjing "kota" diperiksa, sementara anjing-anjing "kampung" diburu untuk dibunuh secara besarbesaran. Alasannya, anjing kampung dianggap sebagai media penularan penyakit rabies.

\section{METODE PENELITIAN}

Penelitian ini dilakukan dengan menggunakan metode sejarah yang terdiri dari empat tahap, yakni heuristik, kritik, interpretasi, dan historiografi. Pada tahap pencarian sumber (heuristik), ditemukan beberapa sumber primer, yakni risalah Departement van Binnenlandsch-Bestuur perihal Ordonansi Anjing Gila pada 1919. Selain itu, digunakan pula majalah De Indische Dierenvriend, yang memuat beritaberita tentang pelanggaran-pelanggaran dalam pemberantasan rabies. Penelitian ini juga memakai beberapa sumber berupa catatan sezaman, foto, dan sumber sekunder lainnya. Sumber-sumber tersebut - secara fisik dan (umumnya) secara substansi kemudian mengalami kritik eksternal dan internal, dengan menguji otentisitas dan kredibilitasnya. Setelah mengalami proses analisis faktual (tahap interpretasi), data- 
data pun dituliskan dalam suatu uraian yang bersifat tematis-kronologis (tahap historiografi).

\section{HASIL DAN PEMBAHASAN}

\section{1 "Keluarga Baru" yang Terinfeksi}

"Beberapa anak muda Belanda, pergi mencari angin di bukit kota tanpa seekor pun satwa aristoktat (anjing) yang melompat-lompat dengan tenang di sampingnya sebagai kawan." (H.W. Ponder, Java Pageant).

H.W. Ponder, seorang perempuan berkebangsaan Inggris, memberikan suatu kesan terkait kebiasaan anak muda (Eropa) yang memiliki kebiasaan "jalan-jalan" bersama anjing peliharaannya. Ponder - yang berada di Jawa sekitar 1930-an melihat anjing-anjing seperti jenis Asaltian, Peking, Jepang, dan King Charles sebagai peliharaan mewah yang memiliki kandang bagus dan besar.

Cerita Ponder tersebut sejatinya memperlihatkan suatu gaya hidup baru yang berkembang pada dekade-dekade awal abad ke-20. Pada masa itu, anjing menjadi suatu penanda status sosial. Anjing dimaknai sebagai kawan yang erat kaitannya dengan keseharian masyarakat, khususnya orang Eropa. Dengan karakteristik yang berbeda, masyarakat pribumi pun menjadikan anjing sebagai penjaga rumah yang hampir dipelihara di setiap rumah pedesaan.

Anjing adalah "keluarga baru", disadari atau tidak. Pemaknaan anjing sebagai bagian dari bagian dari "keluarga" tidak lepas dari masifnya masyarakat memelihara satwa yang sudah didomestikasi sekitar 15.000 tahun lalu tersebut. Anjing difungsikan sebagai teman, yang keberadaannya sangat penting pada setiap rumah, baik orang Eropa maupun orang pribumi. Pada masyarakat pribumi, anjing sudah menjadi teman berburu jauh sebelum datangnya orang Eropa (Boomgaard, 1997: 201). "Tidak ada di setiap rumah tangga pribumi merasa [kehidupannya] lengkap tanpa seekor anjing." Itu pula yang dikatakan H.W. Ponder terkait pentingnya pemeliharaan anjing pada keluarga pribumi. Disebutkan bahwa andjing kamponghampir terlihat di setiap sudut perkampungan. Ia menambahkan bahwa jika berjalan melewati perkampungan, akan ada kondisi menakutkan ketika anjing menggonggong kepada setiap orang dan dari setiap rumah pribumi. Mereka (anjing) kadang terlihat tidak menyukai orang Eropa. Dalam hal ini, anjing menjadi penjaga rumah dimana gonggongannya menjadi semacam alarm, pertanda adanya bahaya ataupun adanya orang asing yang masuk ke rumah (Ponder, 1942b: 163)

Pemaknaan sebagai keluarga bahkan lebih kentara terlihat pada orang Eropa. Anjing menjadi teman bermain yang diperlakukan begitu lembut, harus diasuh, dirawat, dan selalu dibersihkan oleh babu. Posisi anjing pun mengalami suatu transformasi, dari yang awalnya hanya sebatas peliharaan menjadi semacam "keluarga" sesungguhnya - seiring masuknya mereka pada foto keluarga Eropa. Anjing sudah dianggap sebagai anggota keluarga yang seringkali diberi nama dan identitas (kalung/tali) untuk mengenalinya.

Anjing orang Eropa terkesan terurus dengan baik, karena memang berasal dari jenis yang cukup mahal. Berbeda dengan anjing kampung yang umumnya berasal dari jenis Paria India ataupun jenis mongrels Bali, yang terkesan kotor dan tidak terawat. Anjing-anjing ini lah yang dianggap menjadi mediator terjangkitnya 
penyakit rabies sejak akhir abad ke-19, terutama di Jawa dan Sumatera (Schimmel, 2015).

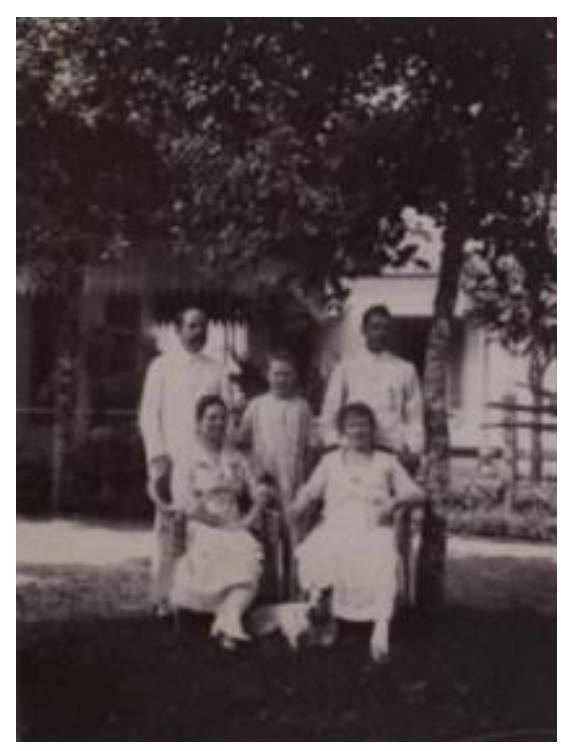

Gambar 1. Anjing dalam potret keluarga Eropa

(Sumber: "FamilieNumans met hunhond in de tuin, vermoedelijk te Soerakarta", Digital Collections Leiden University Libraries, https://digitalcollections.universiteitleiden.nl/, diakses 25 Oktober 2018)

Gejala rabies pada dasarnya telah ada sebelum penyakit tersebut terdeteksi. Rabies pertama kali terdeteksi pada seorang anak di Desa Palimanan, Cirebon tahun 1894 oleh dokter Eilerts de Haan (Renata dalam Historia.id). Namun, gejala rabies pada dasarnya telah terlihat pada kasus seorang serdadu Jawa yang digigit anjing pada 12 Februari 1891. Penanganan pertama terhadap pasien tersebut ialah dengan cara membakar lukanya. Setelah 2 minggu, kondisinya pun membaik, tetapi pada 4 April ia kembali sakit, dengan gejala sakit encok. Pada 27 April 1892, ia meninggal dunia setelah satu hari sebelumnya (26 April) dokter menyatakan bahwa itu merupakan penyakit rabies (Wiggers, t.t.: 17-18). Sejak saat itulah perhatian dan upaya penanganan penyakit rabies mulai dilakukan.

Perhatian khusus terkait rabies dilakukan oleh dokter Eilerts de Haan, yang mendirikan laboratorium Pasteur ${ }^{2}$ di Weltevreden, Batavia pada 1896, yang khusus menangani penyakit rabies (Lombard, 2008: 143). Laboratorium ini - disebut juga Institut Pasteur atau rumah sakit Pasteur. Prosedurnya harus menyertakan surat keterangan dari dokter Belanda ataupun dokter pribumi. Dikarenakan rumah sakit tersebut hanya ada di Batavia, maka para pasien yang berasal dari luar Batavia,

${ }^{2}$ Nama "Pasteur" diambil dari seorang ahli sains dari Perancis, Louis Pasteur, yang berhasil mengidentifikasi cara kerja virus rabies serta berhasil menguji coba vaksin rabies pada 1885. 
mendapat ongkos cuma-cuma dari pemerintah setempat (Departement van Binnenlandsch-Bestuur, 1919: 51-55).

Dalam pengidentifikasiannya, terdapat perbedaan prilaku antara anjing kampong dan anjing "kota" yang terjangkit rabies. Anjing kampong umumnya jarang menggigit, karena sejak kecil tidak terbiasa dekat dengan manusia sehingga anjing-anjing itu akan merasa takut jika bertemu dengan manusia. Berbeda dengan anjing-anjing peliharaan orang Belanda yang sudah terbiasa akrab dengan manusia, sehingga kemudian berani menyerang. Kesulitan penanganannya terletak pada sikap tidak rela dari para pemilik karena anjing-anjing peliharaannya dianggap "gila", terlebih jika anjing-anjing tersebut diharuskan untuk dibunuh (Wiggers, t.t: 12-14). Pembunuhan anjing selanjutnya menjadi hal yang diharuskan, yang anjurannya disahkan melalui undang-undang.

\subsection{Regulasi Anjing Gila dan Permasalahan dalam Cara Membunuh}

Terjangkitnya wabah rabies membuat pemerintah kolonial turun tangan. Wabah ini dianggap cukup meresahkan masyarakat. Selain rehabilitasi, upaya penting lainnya ialah upaya pencegahan. Pencegahan ini mengacu pada penanganan di ranah sumber penyakit. Dalam hal ini, anjing-anjing sebagai sumber penyakit harus diberantas guna menghentikan penularannya.

Salah satu upaya preventif yang dilakukan pemerintah kolonial ialah adanya aturan terkait legalitas kepemilikan anjing yang disertai pemenuhan kebersihannya. Legalitas ini berupa peraturan terkait pajak anjing, dimana tiap ekor anjing dipungut pajak sekitar $f 1$ per tahun. Anjing yang dikenakan pajak diharuskan menggunakan medali di lehernya. Hal tersebut berfungsi sebagai penanda bagi anjing-anjing yang terpantau kebersihannya. Apabila ditemukan anjing yang berkeliaran di jalanan tanpa medali, maka si pemilik akan dikenakan denda sekitar $f 15$. Sementara anjinganjing yang berkeliaran tanpa medali akan ditangkap oleh polisi ataupun dibunuh apabila susah dalam menangkapnya (Departement van Binnenlandsch-Bestuur, 1919: 77-95). Regulasi ini dikeluarkan untuk memerangi penyakit anjing gila. Dengan kata lain, pajak anjing menjadi semacam pencegahan. Anjing berpajak diasumsikan bebas dari penyakit anjing gila atau terpantau perkembangan kesehatannya. Sementara itu, anjing yang tidak berpajak - atau yang berkeliaran - akan dimusnahkan oleh pemerintah karena rentan terjangkit penyakit. Dalam hal ini, anjing-anjing kampong lah yang banyak mengalami pemusnahan (Ponders,1942(b): 163).

Regulasi yang lebih tegas kemudian dikeluarkan pada 1915 setelah dikeluarkannya Undang-Undang Anjing Gila 1915 (Hondsdolheid Ordonantie 1915). Pasal 8 dan 9 undang-undang tersebut secara khusus berisi tentang kewajiban untuk membunuh, membakar, atau mengubur anjing, kucing, dan monyet yang positif terinfeksi rabies. Selain itu, adanya kewajiban untuk mengurung atau mengikat satwa dengan rantai atau tali yang panjangnya tidak lebih dari dua meter (Departement van Binnenlandsch-Bestuur, 1919: 23-26). Legalitas membunuh ini lah yang banyak diprotes para pemerhati kesejahteran satwa, seperti Nederlandsch Indische Vereeniging Bescherming van Dieren (Perkumpulan Pemerhati Satwa Hindia Belanda). 
Perkumpulan ini melihat bahwa proses kematian anjing begitu kejam dan sangat membuat anjing menderita. Perspektif kesejahteraan satwa - yang notabene merupakan perspektif Barat - menilai bahwa kesejahteraan satwa harus terpenuhi bukan hanya saat hidup saja, melainkan juga pada saat kematiannya. Proses kematian yang cepat dan tidak menyakitkan dianggap sebagai kematian yang berlandaskan kesejahteraan satwa. Pemberantasan rabies adalah hal yang sudah seharusnya dilakukan, tetapi tidak harus membuat anjing menderita saat proses pemberantasannya.

Pelanggaran pertama yang diprotes ialah upaya penangkapan dan penahanan anjing yang dilakukan oleh polisi. Polisi memang memiliki wewenang dalam menangkap anjing sesuai dengan undang-undang tersebut. Dalam majalah terbitannya, yakni De Indische Dierenvriend, NIVBD menyebutkan bahwa anjing biasanya kesakitan saat dirantai karena adanya pengekangan pada leher. Selain itu, penderitaan pun terlihat saat polisi memasukkan bambu ke dalam mulut si anjing sebagai penahan - untuk menghindari dari kemungkinan menggigit. Polisi memang banyak melakukan penangkapan anjing kampung yang dianggap terinfeksi dan penyebar rabies. Pengejaran ke pelosok kampung, penahanan paksa, hingga pemusnahan, merupakan tindakan yang dilakukan polisi. Salah satu bentuk pemusnahan tersebut terlihat pada 1925, ketika sekitar 4000 anjing dibantai di Bandung (De Indische Dierenvriend, December 1926).

NIVBD pun mengkritik penahanan anjing dalam suatu penampungan, yang mana begitu rentan terhadap penularan penyakit terhadap anjing yang belum tentu terinfeksi - dalam hal ini anjing peliharaan yang jumlahnya sangat sedikit dibandingkan anjing kampung (De Indische Dierenvriend, September 1926). Seorang dokter hewan, dr. Vrijburg menyatakan bahwa lebih dari $90 \%$ anjing yang ditawan ialah anjing kampung yang rentan sebagai penyebar rabies. Terdapat bukti adanya penahanan dalam kandang kecil, yang membuat empat anjing mati (De Indische Dierenvriend, Juni 1927).

Salah satu bentuk upaya solutif terhadap pelunakan regulasi ialah menawarkan cara membunuh yang tepat - yang dianggap sesuai dengan kaidah "perikesatwaan". Jika dipahami secara sederhana, segala macam bentuk pembunuhan ialah suatu kejahatan, tetapi adanya faktor "keterpaksaan" (harus dibunuh karena penyebar penyakit) adalah pengecualian -yang mana harus dilakukan bukan dengan cara yang membuat satwa menderita pada saat kematiannya.Cara membunuh yang sering dilakukan di kampung-kampung ini, dianggap membuat satwa menderita. Cara lain seperti pembunuhan menggunakan golok yang tajam, setidaknya lebih "manusiawi" karena penderitaan saat kematian terjadi relatif singkat (De Indische Dierenvriend, December 1926). Namun demikian, kedua prosedur membunuh tersebut cenderung membuat anjing menderita.

Salah satu cara membunuh yang dipraktikkan NIVBD ialah pembunuhan dengan menggunakan gas batu bara. Perangkat ini terdiri atas kandang yang disertai penutupnya serta saluran (selang) untuk memasukkan gas batu bara. Sistem kerjanya ialah ketika kandang telah tertutup, gas kemudian menyebar ke dalam kandang. Piranti yang telah digunakan di London sejak 1894 ini, menghasilkan karbonmonoksida (CO). Pada kadar 10-20\%, CO akan menyebabkan anjing mengalami ketidaksadaran selama 15-20 detik, hingga mati dalam beberapa menit kemudian (De Indische Dierenvriend, December 1926). 


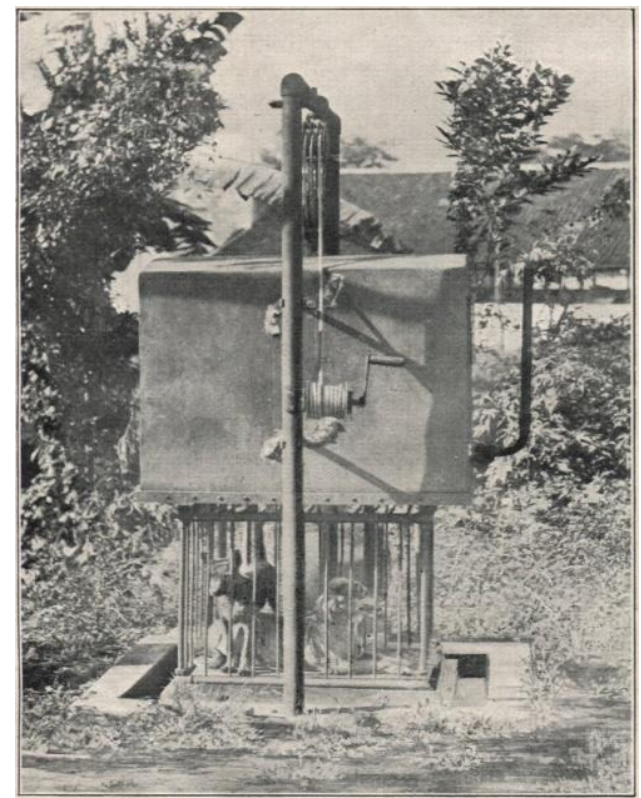

Gambar 2. Piranti Gas Batu Bara untuk Membunuh Anjing

(Sumber: "Het afmaken van kleinedieren", De IndischeDierenvriend: Orgaan van de Nederlandsch-Indische Vereeniging tot Bescherming van Dieren, No. 2, 1e Jaargang, December 1926)

NIVBD menganggap cara membunuh tersebut lebih "manusiawi" dibandingkan membunuh dengan cara-cara lama. Salah satu penggunaan piranti ini terlihat di Surabaya, dimana penduduk kota dan juga penduduk di kota kabupaten membawa tangkapannya (anjing kampung), untuk dibunuh dengan gas Verslaag van Nederlandsch-Indische Vereeniging tot Bescherming van Dieren 1916 en 1917). Pada awal dekade kedua abad ke-20, NIVBD memutuskan untuk tidak lagi mamakai piranti tersebut, dikarenakan rumitnya perbaikan alat, biaya layanan yang besar, serta rentannya kerusakan alat seiring kondisi cuaca Hindia yang lembab. Setelah ditinggalkannya cara itu, penggunaan gas untuk membunuh masih dilakukan, misalnya masyarakat Medan menggunakan gas dari arang sebagai pengganti batu bara (De Indische Dierenvriend, December 1926).

Upaya pemberantasan rabies yang lebih lunak tidak bisa dilepaskan dari berdirinya dieren asyl (tempat penampungan satwa) dan dieren hospital (rumah sakit hewan). Di kedua tempat inilah kegiatan rehabilitasi, mulai dari penampungan, karantina, pengobatan, juga pembunuhan yang lebih "manusiawi" dilakukan. Tujuannya bukan hanya untuk penanggulangan penyakit rabies, tetapi juga hal-hal lain yang berkaitan dengan kesehatan satwa. Sejak 1926, di beberapa kota, seperti Bandung, Batavia, dan Semarang, telah dijajaki secara serius pembuatan rumah sakit satwa (dieren-hospital) serta rumah bagi satwa-satwa terlantar (dieren-asyl). (De Indische Dierenvriend, September 1926). 


\section{PENUTUP}

Anjing memiliki peran penting dalam kehidupan manusia, yang secara kultural dianggap sebagai "partner, bahkan "keluarga baru". Namun, wabah rabies kemudian mengubah relasi ini. Anjing sebagai peliharaan berharga (secara nilai dan fungsi) terpaksa harus dibunuh. Namun demikian, terjadi suatu perubahan sikap pada masyarakat untuk lebih menjaga aspek higienitas anjingnya sebagai suatu bentuk "kasih sayang baru". Pembunuhan anjing sebagai bagian dari penanggulangan wabah memperlihatkan suatu dilema bagi para pemerhati kesejahteraan satwa. Di satu sisi, anjing-anjing terinfeksi harus diberantas, namun di sisi lain mereka prihatin mengenai cara pembunuhan yang dilakukan. Jalan tengahnya adalah menawarkan cara membunuh yang sesuai dengan nilai-nilai kesejahteraan satwa. Meski aspek yang ditawarkan tidak terlalu besar pengaruhnya, setidaknya hal tersebut memberikan bukti bahwa sudah ada keseriusan dalam penegakan kesejahteraan satwa, khususnya dalam penanggulangan wabah rabies pada masa kolonial.

\section{DAFTAR PUSTAKA}

Boomgard, Peter. 1997. "Hunting and Trapping in Indonesia Archipelago, 1500-1950" dalam Peter Boomgard, Freek Colombijn \& David Henley. Paper Landscape; Exploration in The Environmental History of Indonesia. Leiden: KITLV Press

C Lombard, Denys. 2008. Nusa Jawa: Silang Budaya bagian I: Batas-Batas Pembaratan, (Jakarta: Gramedia Pustaka Utama)

De Indische Dierenvriend: Orgaan van de Nederlandsch-Indische Vereeniging tot Bescherming van Dieren, No. 1, 1e Jaargang, September 1926. “De hondsdolordonantie".

De Indische Dierenvriend: Orgaan van de Nederlandsch-Indische Vereeniging tot Bescherming van Dieren, No. 2, 1e Jaargang, December 1926. "Het afmaken van kleinedieren"

De Indische Dierenvriend: Orgaan van de Nederlandsch-Indische Vereeniging tot Bescherming van Dieren, No. 4, 1e Jaargang, Juni 1927. "De nieuwehondsdolheid-ordonantie in de praktijk"

Departement van Binnenlandsch-Bestuur. 1919. Handleiding ten dienste van de Inlandsche Bestuursambtenaren No.21/L. N. H. Hondsdolheid-Ordonantie $\mathcal{E}$ Instituut-Pasteur te Weltevreden Hondenbelasting. (Weltevreden, Indonesische Drukkerij)

Detik.com, 19 Maret 2019, “ KLB Rabies, Sudah 987 Anjing Dimatikan di Sumbawa NTB", https://news.detik.com/berita/d-4473941/klb-rabies-sudah-987anjing-dimatikan-di-sumbawa-ntb, diakses 16 Desember 2019

\begin{tabular}{llr} 
Digital & \multicolumn{1}{c}{ Collections } & Leiden \\
& Libraries,https://digitalcollections.universiteitleiden.nl/, & "Familie \\
& Numans met hunhond in de tuin, vermoedelijk te Soerakarta", diakses 25 \\
& Oktober 2018
\end{tabular}

Ponder, H.W. 1942. Java Pageant. London: Seeley \& Co 
Kesejahteraan Anjing dalam Pemberantasan Wabah Rabies di Hindia Belanda 1942. Java Panorama. London: Seeley \& Co

Renata, Mira. historia.id, https://historia.id/sains/articles/menghapus-rabiesvQ4BD, diakses 17 Desember 2019

Schimmel. (2015). "Rabies in Nederlandsch-Indie", Nederlands Tijdschrift voor Geneeskunde publication.

Wiggers, F. Peratoeran boewat Institut Pasteur di Weltevreden 